\title{
CONTENTS
}

A wrocelure for the preparation of benzene from $C$

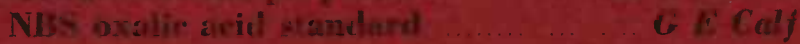

\section{DATE HITS}

Jim I Mind, Rubert S Thomposin, nud Austin ling

Aricuma fladiscartoon Dates IX:

Carłon Isotope Dating of Packiat Mildens

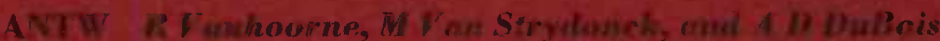

Antwerp Univergity Radiocatbon Dates II

DE LJSeliroder, $R$ I. Emeran, and W A Bectem

US Grological Sursey, Derwer, folorado

Radiocartoon Datae in

P Rernaid Fishman and Mrerbara Lawn

University of Pennsyivamia

Racliocarhon Dates XX

PRI II $P$ Agruwal, $R$ V Krishnanurthy. Sheele Kusumiar, and R K Pront Phyaical fiecarch Latberatory Radiocarthom Date List II

Tx SValasero, Jr, E Mott Dovis, and Alejundra G Vurele University of Texas at Austio Radiocarbon Dates Xili

UM M Calvert, Kins Rudolph, and J J Stips University of Miami Radiocerbon Dates XII

USGS l.en Kelley, Elliou Spiker, and Mover Rubin US Geologital Survey, Restan, Virginia, Fudincarbon Dates XV 